\title{
CSR Orientation from the Mexican Businessmen Perspective of Service Enterprises
}

\author{
Teodoro Rafael Wendlandt Amezaga ${ }^{1}$, Marco Alberto Nuñez Ramírez ${ }^{1}$, José Luis Camarena Martínez ${ }^{1}$ \& \\ Brenda Yuriria Bejarano Lugo ${ }^{1}$ \\ ${ }^{1}$ Department of Management, Instituto Tecnológico de Sonora, Sonora, México \\ Correspondence: Teodoro Rafael Wendlandt Amezaga, Department of Management, Instituto Tecnológico de \\ Sonora, Calle 5 de febrero No. 818 sur, Sonora, C.P. 85000, Ciudad Obregón, Sonora, México. E-mail: \\ teodoro.wendlandt@itson.edu.mx
}

Received: November 16, $2016 \quad$ Accepted: December 7, $2016 \quad$ Online Published: January 25, 2017

doi:10.5539/jms.v7n1p54 URL: http://dx.doi.org/10.5539/jms.v7n1p54

\begin{abstract}
The present study aimed to know the businessmen perception in Mexico regarding the four social responsibilities originally proposed by Carroll (1979); to that end, the investigation proposed to determine if there are differences between the values assigned by the businessmen for each of the social responsibilities, and in case of significant differences, to contrast these responsibilities in order to identify any pattern of relative importance among them. Additionally, the study also sought to determine significant correlations between the social responsibilities of business organizations. By means of a non-probabilistic sampling method, information was collected from a sample of 150 entrepreneurs of the service sector from a city located in a northwestern state of Mexico. The research results contribute with empirical evidence on the orientation of the corporate social responsibility in this country, by identifying differences and significant correlations between the social responsibilities. Furthermore, similarities were foundin the pattern of relative importance given to these responsibilities by businessmen in Mexico and other countries, reinforcing the idea that the economic dimension is the most important social responsibility for the business sector.
\end{abstract}

Keywords: CSR, Mexico, enterprise, businessmen, service

\section{Introduction}

As a result of the rapid changes in the international environment and the global integration of the markets, in recent years companies have been characterized for adopting strategic approaches such as risk management (e.g., Godfrey, Merrill, \& Hansen, 2009), management of the stakeholder relations (e.g., Buysse \& Verbeke, 2003; Verbeke \& Tung, 2013), and the management of marketing (e.g., Homburg, Kuester, \& Krohmer, 2013). These changes have generated that managers seek to maintain a good relationship with the communities in which they operate, in addition to contributing to society through activities, plans and strategic programs of social responsibility (Mukherjee \& Bird, 2016; Nasrullah \& Rahim, 2014; Painter-Morland \& Vashchenko, 2014). It is important to mention that when implementing these social actions, research has shown that the business organizations tend to obtain certain benefits like improvements of the corporate image (Brown \& Deegan, 1998), sustainable competitive advantages, and increases in the company reputation (Esrock \& Leichty, 1998; Freeman, 2006; Lichtenstein, Drumwright, \& Braig, 2004).

When conducting a literature review on the topic of corporate social responsibility (CSR), it is possible to realize that most of the international studies on this variable from the business perspective have been carried out in developed countries such as the United States, England, France, Germany, Japan and Sweden (Aupperle, Carroll, \& Hatfield, 1985; Edmondson \& Carroll, 1999; Pinkston \& Carroll, 1996); however, there is still a need to investigate that perspective in developing countries such as Mexico, where there is no empirical evidence on this orientation in spite of the increases in the socially responsible communications during recent years (Meyskens \& Paul, 2010; Paul et al., 2006). Once CSR orientation be known in this country and there exist information available, it will be possible to compare the results and review the similarities with previous studies, in addition to compare this perspective with that of other interest groups or stakeholders (e.g., consumers).

Taking in consideration the above mentioned, the present study was proposed to know the perception that businessmen have in Mexico with respect to the four social responsibilities proposed originally by Carroll (1979); 
to do this, research was proposed initially to determine if there are differences between the values assigned by the businessmen for each of the social responsibilities, and in case of obtaining significant differences, contrasting these responsibilities in order to identify any pattern of relative importance between them. Finally, the study also sought to determine significant correlations between the social responsibilities of companies.

For the achievement of these objectives, first, the CSR concept and its dimensions are presented, in addition to a brief description of the empirical studies that have been developed from the business perspective; next, some research hypotheses with its theoretical foundations are raised; the methodology and research design characteristics utilized to conduct the study are mentioned; then results are presented and the main findings discussed in accordance with the research hypotheses; some ideas are suggested for further studies; and finally, the study is concluded and the importance on continuing the research on this topic is highlighted.

\section{Literature Review}

\subsection{Corporate Social Responsibility and Its Four Dimensions}

Although within the literature, there is diversity of theoretical perspectives and a large number of concepts about CSR (e.g., Carroll, 1999, 2008; Dahlsrud, 2008; Moura-Leite \& Padgett, 2011), this has resulted in a lack of consensus and much confusion about its definition, preventing that comparable investigations are carried out that allow the comparison between countries and groups of people (McWilliams, Siegel, \& Wright, 2006). However, for the purposes of this study the definition proposed by Archie Carroll in 1979 will be used, which is considered to be one among the most durable, disseminated and recognized in the academic literature (Crane \& Matten, 2010).

According to this author, CSR is the one that encompasses "the economic, legal, ethical, and discretionary expectations that society has of organizations at a given point in time" (Carroll, 1979, p. 500). Base on this definition, CSR includes four dimensions or types of responsibilities society expects companies to take. In addition, the author himself points out that the four responsibilities are not mutually exclusive and are neither cumulative nor summative, but simultaneous and changing at each moment in time.

The economic dimension is concerned with the responsibility of producing goods and services that society requires, in addition to selling them with their respective profit margin; the legal dimension is associated with the implementation of the legal aspects imposed by each society, which they delimit and regulate the actions of the companies; the ethical dimension is related to the fulfillment of moral and ethical standards that society expects from companies, whose activities and behaviors are not necessarily formalized in laws; and finally, the discretionary dimension -subsequently named as philanthropic by Carroll (1991) it refers to all those voluntary activities that are not required by law or not expected by the society from an ethics point of view. Below are each of the social responsibilities and the relative weights attributed by the own Carroll (1979, see Figure 1).

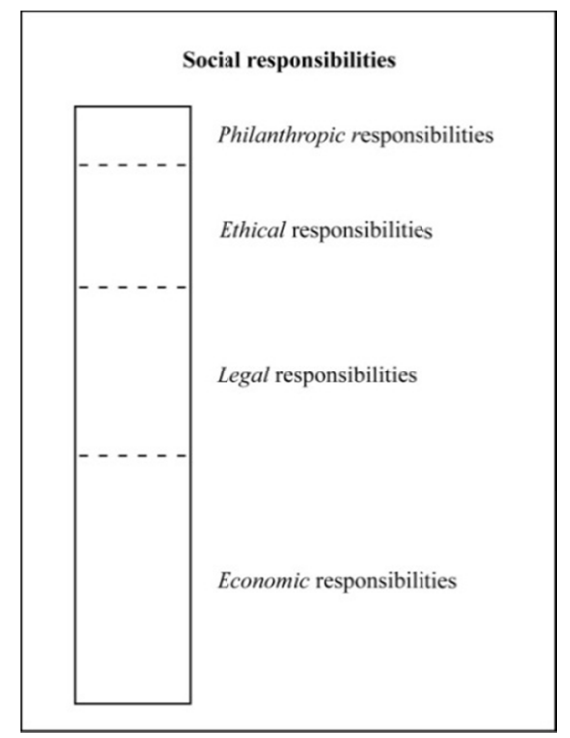

Figure 1. Relative weights attributed to each social responsibility

Note. Elaborated with information obtained from Carrol (1979, p. 499). 


\subsection{Empirical Studies Regarding the Social Responsibilities from the Businessmen Perspective}

In consideration of the four dimensions of the CSR and its value from the business perspective, it should be noted that there are previous empirical studies that have used the same definition proposed by Carroll (1979) to address this issue (e.g., Aupperle, Carroll, \& Hatfield, 1985; Pinkston \& Carroll, 1996; Edmondson \& Carroll, 1999; Maignan \& Ferrell, 2000). Below are presented the general characteristics of these investigations of reference (see Table 1).

Table 1. Empirical studies that have used the definition of CSR proposed by Carroll (1979)

\begin{tabular}{|c|c|c|c|}
\hline Authors & Year & Country & Perspective/approach \\
\hline Aupperle, Carroll, \& Hatfield & 1985 & $\begin{array}{l}\text { International } \\
(n=241)\end{array}$ & $\begin{array}{l}\text { Businessmen } \\
\text { (managers) }\end{array}$ \\
\hline Pinkston \& Carroll & 1996 & $\begin{array}{l}\text { U. S. }(n=49) \\
\text { England }(n=23) \\
\text { Germany }(n=23) \\
\text { France }(n=11) \\
\text { Japan }(n=9) \\
\text { Switzerland }(n=9) \\
\text { Sweden }(n=7)\end{array}$ & $\begin{array}{l}\text { Businessmen } \\
\text { (managers) }\end{array}$ \\
\hline Edmondson \& Carroll & 1999 & U. S. $(n=74)$ & Managers/Owners \\
\hline Maignan \& Ferrell & 2000 & $\begin{array}{l}\text { U.S. }(n=210) \\
\text { France }(n=120)\end{array}$ & $\begin{array}{l}\text { Businessmen } \\
\text { (managers) }\end{array}$ \\
\hline
\end{tabular}

Note. Own elaboration. U. S. = United States of America.

In the first study by Aupperle, Carroll, \& Hatfield (1985) it is seeked to measure the CSR and their relationship with the profitability, this by gathering information from 241 heads of companies registered in the annual directory of Forbes in 1981. The results enabled the authors provide empirical evidence that actually indicates that there are four independent CSR components, and that these are correlated to some extent, obtaining a negative correlation between the economic responsibility and the others dimensions; this adds to the relative importance attributed to each responsibility, similar to the relative weights proposed originally by Carroll (1979).

The study by Pinkston \& Carroll (1996) was aimed at re-examining the orientation of managers with respect to the four social responsibilities, with the purpose of determining any change or evolution in social expectations. This research considered a sample of 131 managers of companies from different countries in the chemical sector and its by-products. In general, the findings showed a greater importance attached to economic responsibility, followed by the legal, ethical and discretionary (or philanthropic) responsibilities; the latter was obtained in all but the Swedish and German companies who placed the legal as the most important dimension.

Additionally, Edmondson \& Carroll (1999) conducted research on philanthropy (activities, impacts, motivations and orientation of the CSR) in large enterprises propertyof African-American entrepreneurs and stockholders, gathering information from a sample of 74 organizations. The results obtained regarding the orientation of CSR in this type of companiesshowed a higher score to the economic dimension, followed by the ethical, legal and philanthropic dimensions, a finding that contrasts with the non-numerical weights proposed by Carroll.

Finally, the investigation by Maignan \& Ferrell (2000) as a result of an extensive literature review- proposed a concept of corporate citizenship and operationalized it using a measuring instrument that includes the four dimensions of Carroll's CSR definition. In their study, the authors define corporate citizenship as "...the measure in which the companies meet the economic, legal, ethics and discretionary responsibilities imposed on them by their groups of interest" (p. 284); in addition to developing and validating a measuring instrument, the authors applied it to a mixed sample of American and French business administrators.It should be noted that this research results did not consider the order of priority or relative importance granted to each of the social responsibilities.

\subsection{Research Hypotheses}

Taking into consideration the theoretical basis of the four social responsibilities of companies and the relative weights proposed initially by Carroll (1979), in addition to the main results obtained in the last 30 years in previous studies carried out at the international level (Aupperle, Carroll, \& Hatfield, 1985; Pinkston \& Carroll, 1996; Edmondson \& Carroll, 1999; Maignan \& Ferrell, 2000), it is possible to consider obtaining significant differences and the following order of relative importance that will be assigned by businessmen in Mexico for each of the four social responsibilities of companies. Therefore, below are described the research hypotheses of 
this study:

Hypothesis 1. There exist significant differences in the relative importance attached by businessmen of Mexico with regard to the four social responsibilities of companies.

Hypothesis 2. The order of relative importance attributed by Mexican businessmen with regard to the four social responsibilities of companies will be the following: (1) economic, (2) legal, ethical (3) and (4) philanthropic.

\section{Method}

\subsection{Study Participants}

The present research employed a quantitative approach and non-experimental design, whose scope was descriptive, correlative and comparative. The population to study were the businessmen of the service sector, which through a non-probability sampling method, information from a sample of 150 entrepreneurs in a north-western Mexican state was collected, being these people mostly owners of such organizations. It should be noted that during all the research process, special care was taken in ensuring that participants were representing the characteristics of the business sector considered, being this sector which contributes to a greater extent to the Gross Domestic Product (GDP) of the country, according to the National Institute of Statistics and Geography ([INEGI, by its acronym in Spanish] www.inegi.org.mx).

Among the main features of the participants who responded the instrument were: their average age $(M)$ of 40.4 years, with a standard deviation $(S D)$ of 11.6 years, this within a range of 50 years (from 18 to 68 years); this in addition to perceive a monthly average income of $\$ 14,000$ pesos (MXN; around $700 \mathrm{USD}$ ) and to have an average experience (seniority) within the organization of 8.7 years (see Table 2).

Table 2. Characteristics of the participants in the study $(n=150)$

\begin{tabular}{lll}
\hline Characteristics & $N$ & $\%$ \\
\hline Sex & & \\
Male & 79 & 52.7 \\
Female & 71 & 47.3 \\
\hline Level of education & & \\
Basic education & 81 & 54 \\
Higher education & 61 & 40.7 \\
Postgraduate studies & 8 & 5.3 \\
\hline Position of responsibility & \\
Owner & 104 & 69.3 \\
Manager & 46 & 30.7 \\
\hline Size of the company (employees) & & \\
Micro (1-10) & 128 & 85.3 \\
Small (11-50) & 22 & 14.7 \\
\hline
\end{tabular}

Note. Own elaboration.

\subsection{Measurement Instrument}

The measurement instrument for data collection was composed of two sections, the first to obtain sociodemographic information and the second to assess the four social responsibilities. Each of the corresponding scales is described below:

Sociodemographic data. In this first section, information about the general characteristics of the subjects participating in the research was collected, allowing to realize the pertinent categorizations for its statistical analysis. Among the features requested in the instrument are: age, sex, educational level, seniority in the company, income level (monthly), working position (position of responsibility), and company size (determined by the number of employees).

Social responsibilities. To measure these dimensions, the scale proposed by Maignan (2001) was used, which is based on the theoretical model of Carroll $(1979,1991)$, who states that "business encompasses the economic, legal, ethical and discretionary expectations that society has of organization at a given point in time" (Carroll, 1979, p. 500). The scale to measure CSR was integrated by a total of 16 items (four for each responsibility), which was answered by a Likert-type scale with six response options (ranging from 1 [Totally disagree] to 6 [Totally agree]), where a higher score was an indicative of a greater degree of consistency or level of agreement with each of the statements of each dimension.It should be noted that the questions were translated and adapted 
to the Spanish language through the support of competent professional staff to do this, the latter by following the recommendations issued by Churchill (1979). The four dimensions of CSR and their respective questions are shown below (See Table 3).

Table 3. Scale to measure CSR and its four dimensions

\begin{tabular}{|c|c|c|}
\hline Dimensions & Definition & $\begin{array}{l}\text { Items* } \\
\text { "I believe that businesses must..." }\end{array}$ \\
\hline Economic & $\begin{array}{l}\text { It reflects the belief that companies } \\
\text { are required to be productive and } \\
\text { profitable, to meet the needs of its } \\
\text { consumers. }\end{array}$ & $\begin{array}{l}\text { Item 1. Maximize profits } \\
\text { Item 2. Control their production costs strictly } \\
\text { Item 3. Plan for their long term success } \\
\text { Item 4. Always improve economic performance }\end{array}$ \\
\hline Legal & $\begin{array}{l}\text { Reflects the expectations of each } \\
\text { society to observe that companies } \\
\text { are within the framework of the } \\
\text { legal requirements and comply with } \\
\text { the pertinent regulations. }\end{array}$ & $\begin{array}{l}\text { Item 5. Ensure that their employees act within the standards defined by the } \\
\text { law } \\
\text { Item 6. Refrain from putting aside their contractual obligations } \\
\text { Item 7. Refrain from bending the law even it this helps improve performance } \\
\text { Item 8. Always submit to the principles defined by the regulatory system }\end{array}$ \\
\hline Ethical & $\begin{array}{l}\text { It reflects the codes, values and } \\
\text { unwritten rules that are implicitly } \\
\text { derived from each society; it is } \\
\text { expected that the companies comply } \\
\text { with an appropriate behavior. }\end{array}$ & $\begin{array}{l}\text { Item 9. Permit ethical concerns to negatively affect economic performance } \\
\text { Item 10. Ensure that the respect to ethical principles has priority over } \\
\text { economic performance } \\
\text { Item 11. Be committed to well-defined ethics principles } \\
\text { Item 12. Avoid compromising ethical standards in order to achieve corporate } \\
\text { goals }\end{array}$ \\
\hline Philanthropic & $\begin{array}{l}\text { Is voluntary in nature and reflects } \\
\text { the common desire to observe that } \\
\text { companies are actively involved in } \\
\text { the improvement of each society. }\end{array}$ & $\begin{array}{l}\text { Item 13. Help solve social problems } \\
\text { Item 14. Participate in the management of public affairs } \\
\text { Item 15. Allocate some of their resources to philanthropic activities } \\
\text { Item 16. Play a role in our society that goes beyond the mere generation of } \\
\text { profits }\end{array}$ \\
\hline
\end{tabular}

Note. Own elaboration. *Items obtained from "Consumers' Perceptions of Corporate Social Responsibilities: A Cross-Cultural Comparison," by I. Maignan, 2001, Journal of Business Ethics, 30, p. 64.

\subsubsection{Validity and Reliability of the Measurement Instrument}

Once defined the construct, its dimensions and the corresponding questions, the scale was submitted to content validity by means of the opinion of three experts in the topic, to whom once explained the purpose of the research, they were asked to assess each of the items of the scale as "adequate" or "not adequate," and to issue recommendations for improvement in terms of aspects such as writing, clarity and theoretical consistency. Next, the Kappa coefficient (inter-rater reliability) was calculated, obtaining a very acceptable score of .95 (Abraira, 2001; Escobar-Pérez \& Cuervo-Martínez, 2008).

Subsequently, as part of the validity criteria, it was verified that the measuring instrument maintained an adequate factorial structure (construct validity), reason by which an exploratory factor analysis trough the principal components method and varimax rotation was performed, taking as assumption the independence of the factors constituting the instrument (Cea, 2002). The results of the analysis showed a Kaiser-Mayer-Olkin index of .747 , a significant Bartlett's test of sphericity $\left(X^{2}=885.78, \mathrm{gl}=120, p<.001\right)$, a determinant of .002 , and factorial loads greater than .45 in all questions (Hair, Anderson, Tatham, \& Black, 2000; Pett, Lackey, \& Sullivan, 2003). Moreover, taking the Kaiser-Guttman criterion -eigenvalues greater than one-for the inclusion of factors in the factorial structure (Martínez, Hernández, \& Hernández, 2006), is that a solution constituted by four factors that explain a $61.87 \%$ of the variance of the total scores of the measuring instrument was obtained.The first factor (philanthropic) explained the $27.35 \%$ of the scores'variance, followed by the second (legal) factor with $16.18 \%$, the third (economic) factor with $11.64 \%$, and finally the fourth factor (ethical) with $6.68 \%$. The questions were grouped according to their corresponding theoretical dimension, without having to remove any of the questions (see Table 4).

Finally, the reliability of the instrument was obtained by the Cronbach Alpha coefficient $(\alpha)$, which resulted in .804 for the scale in general, being located above .70; a number that is considered as the limit to be accepted in this type of analysis (Martínez, Hernández, \& Hernández, 2006). In this regard, the economic dimension obtained a $\alpha=.70$, the legal dimension $\alpha=.79$, ethics $\alpha=.73$, and philanthropic with an $\alpha=.82$, being adequate the internal consistency of each dimension $(\alpha \geq .70)$. 
Table 4. Summary of items and factorial loads of the exploratory factor analysis $(n=150)$

\begin{tabular}{|c|c|c|c|c|c|}
\hline \multirow[b]{2}{*}{ Items } & \multicolumn{5}{|c|}{ Factorial loads } \\
\hline & 1 & 2 & 3 & 4 & h2 \\
\hline Item 1. Maximize profits & -.11 & .10 & .77 & .03 & .61 \\
\hline Item 2. Control their production costs strictly & -.04 & .04 & .78 & -.18 & .65 \\
\hline Item 3. Plan for their long term success & .08 & -.13 & .64 & .23 & .49 \\
\hline Item 4. Always improve economic performance & .06 & .23 & .67 & .17 & .54 \\
\hline $\begin{array}{l}\text { Item } 5 \text {. Ensure that their employees act within the standards defined } \\
\text { by the law }\end{array}$ & .00 & .78 & .17 & .08 & .65 \\
\hline Item 6. Refrain from putting aside their contractual obligations & .07 & .80 & .03 & .13 & .67 \\
\hline $\begin{array}{l}\text { Item 7. Refrain from bending the law even it this helps improve } \\
\text { performance }\end{array}$ & .01 & .79 & -.03 & .05 & .63 \\
\hline $\begin{array}{l}\text { Item } 8 \text {. Always submit to the principles defined by the regulatory } \\
\text { system }\end{array}$ & .04 & .67 & .07 & .38 & .61 \\
\hline $\begin{array}{l}\text { Item } 9 \text {. Permit ethical concerns to negatively affect economic } \\
\text { performance }\end{array}$ & .04 & .14 & .07 & .72 & .55 \\
\hline $\begin{array}{l}\text { Item } 10 \text {. Ensure that the respect to ethical principles has priority } \\
\text { over economic performance }\end{array}$ & .14 & .36 & .35 & .59 & .61 \\
\hline Item 11. Be committed to well-defined ethics principles & .38 & .32 & .06 & .56 & .57 \\
\hline $\begin{array}{l}\text { Item 12. Avoid compromising ethical standards in order to achieve } \\
\text { corporate goals }\end{array}$ & .27 & .05 & -.01 & .75 & .64 \\
\hline Item 13. Help solve social problems & .65 & .06 & -.09 & .39 & .59 \\
\hline Item 14. Participate in the management of public affairs & .82 & .06 & .03 & .15 & .70 \\
\hline Item 15. Allocate some of their resources to philanthropic activities & .84 & .04 & .07 & .04 & .72 \\
\hline $\begin{array}{l}\text { Item 16. Play a role in our society that goes beyond the mere } \\
\text { generation of profits }\end{array}$ & .82 & -.03 & -.05 & .11 & .69 \\
\hline
\end{tabular}

Note. Bold numbers indicate the highest factor loads. $h^{2}=$ communality.

\subsection{Procedure}

For the sake of data collection, the purpose of the investigation was explained to the administrators of the companies and its authorization requested; its participation in the study was voluntary as well. Also, it was made clear the confidentiality of the information provided, being used only for the stated research purposes.For data analysis, the statistical software IBM SPSS (version 22) was utilized, wherein the analysis of variance and corresponding descriptive, correlative and comparative statistical analyses were performed.It is worth noting that a repeated-measure design was used due to the fact that the same subjects were measured under different conditions (CSR dimensions), being the responses originated from the same individuals (dependent scores) under equal circumstances (Singh, Rana, \& Singhal, 2013).

\section{Results}

\subsection{Businessmen Perception and Differences between CSR Dimensions}

The findings show that in general, the perception that businessmen have on corporate social responsibility is high $(M=5.20)$, in addition to the fact that three of the four responsibilities averaged above five points, with the exception of the philanthropic dimension (see Table 5). Moreover, through bivariate correlation statistical analyses between each pair of the CSR dimensions, it was possible to identify the existence of positive and statistically significant relationships between some of these responsibilities, although such associations were relatively low mostly (Hinkle, Wiersma, \& Jurs, 2003).

Among the main findings was that the economic responsibility isn't related tothe philanthropic responsibility, in addition to a very weak or insignificant correlation with the ethical and legal dimensions; furthermore, the ethical responsibility showed a weak relationship with the legal dimension, and a moderate association with the philanthropic responsibility (the coefficients are shown in Table 5).

Table 5. Descriptive data and bivariate correlations coefficients among CSR dimensions

\begin{tabular}{lllllll}
\hline CSR $^{1}$ dimensions & $M$ & $S D$ & Economic & Legal & Ethical & Philanthropic \\
\hline Economic & 5.61 & 0.41 & - & & & \\
Legal & 5.43 & 0.55 & $.27^{* *}$ & - & & \\
Ethical & 5.05 & 0.79 & $.28^{* *}$ & $.46^{* *}$ & - & $.52^{* *}$ \\
Philanthropic & 4.72 & 0.75 & .05 & $.21^{* *}$ & - \\
\hline
\end{tabular}

Note. Own elaboration. ${ }^{1}$ Corporate social responsibility. ${ }^{* *} p<.01$ (two-tailed). 
For the identification of differences in the businessmen preferences with regard to the responsibilities, a one-way repeated measures analysis of variance (ANOVA) was used. As can be seen in the following Table 6, the test result suggests the existence of significant differences between the values assigned by the businessmen for each of the dimensions in particular.

Table 6. Results of repeated measures ANOVA for the identification of differences among dimensions

\begin{tabular}{lllllll}
\hline Source & $d f$ & $S S$ & $M S$ & $F$ & $p$ & $\eta^{2}$ \\
\hline Between-group & 3 & 72.23 & 24.08 & 86.23 & .001 & .36 \\
Within-group & 459 & 128.15 & 0.28 & & & \\
Total & 462 & 200.38 & & & & \\
\hline
\end{tabular}

Note. Obtained results through the SPSS program.

Once differences between the responsibilities were identified, each of these dimensions were contrasted with the purpose of determining any order or pattern of importance between them, for which the Bonferroni method was used as a Post Hoc test. The obtained results suggest that it is possible to establish such a pattern of priority between the dimensions, reaching first the economic dimension, followed by the legal responsibility, then the ethical responsibility, and finally the philanthropic dimension (see Table 7).

Table 7. Post Hoc test for the comparison of mean scores of the CSR dimensions

\begin{tabular}{llllll}
\hline & CSR dimensions & & & & \\
& Economic (1) & Legal (2) & Ethical (3) & Philanthropic (4) & \\
Dimensions & $M$ & $M$ & $M$ & $M$ & Post hoc \\
\hline Economic & - & $5.43^{* * *}$ & $5.05^{* * *}$ & $4.72^{* * *}$ & $1>2,3,4$ \\
Legal & $5.61^{* * *}$ & - & $5.05^{* * *}$ & $4.72^{* * *}$ & $2<1 ; 2>3,4$ \\
Ethical & $5.61^{* * *}$ & $5.43^{* * *}$ & - & $4.72^{* * *}$ & $3<1,2 ; 3>4$ \\
Philanthropic & $5.61^{* * *}$ & $5.43^{* * *}$ & $5.05^{* * *}$ & - & $4<1,2,3$ \\
\hline
\end{tabular}

Note. The numbers in parentheses in column heads refer to the numbers used for illustrating significant differences in the "Post hoc" column. For all measures, higher means indicate higher dimensions agreement. The comparison of means was performed using the Bonferroni method. The differences were significant at $p<.001$.

\subsection{Discussion}

In general, the present study had as purpose to know the perception that Mexican businessmen have on the four social responsibilities of companies originally proposed by Carroll (1979); in particular, the research sought to determine if there are significant correlations anddifferences in the values assigned by these subjects for each one of the dimensions, contrasting the responsibilities to identify any possible pattern of importance attributed to these dimensions.

With regard to the results obtained, it is possible to point out that the perception of Mexican businessman on social responsibilities is high, reaching an average above the five points $(M=5.20)$. Furthermore, taking in consideration the research hypotheses, the statistical results suggest the existence of significant differences between the values assigned by these subjects for each dimension, in addition to prove the existence of a given pattern of importance between the social responsibilities (economic-legal-ethical-philanthropic).

When comparing the main findings of this study with previous research at the international level, which also addresses the business perspective (business managers) on the social responsibilities of companies (see Table 8), it is possible to notice certain similarities in the results; the economic responsibility is the most valued (with an overall average of 3.29), followed by the legal responsibility (2.90), then the ethical responsibility (2.39), and finally the philanthropic responsibility (1.27). It should be noted that both, the results of this study and previous international investigations, show an order of relative importance very similar to the proposed originally by Carroll (1979). This suggests that the perspective of businessmen tends to be homogeneous among countries in the values attributed to the social responsibilities, being the economic dimension the most important to the business sector. Among the diverse views or perspectives on the subject, these findings appear to support the famous objection and posture of Milton Friedman in 1962, who quoted: "few trends could so thoroughly undermine the very foundations of our free society as the acceptance by corporate officials of a social responsibility other than to make as much money for their stockholders as possible" (Friedman, 1962, p. 133). 
With regard to the correlations between the CSR dimensions, the results obtained in the present study do not present any similarity with previous research, being only Aupperle, Carroll, \& Hatfield (1985) who reported these correlations (p. 458). Finally, it is necessary to mention the relative importance of the ethical component (or factor) in its association with other dimensions, this due to the fact that in this factor were found the relationships of greater magnitude.

Table 8. Results of previous research on the social responsibilities

\begin{tabular}{lllll}
\hline $\begin{array}{l}\text { Previous research } \\
\text { Economic }\end{array}$ & Legal & Ethical & Philanthropic \\
\hline $\begin{array}{l}\text { Aupperle, Carroll, \& Hatfield (1985) } \\
\text { International }\end{array}$ & 3.50 & 2.54 & 2.22 & 1.30 \\
\hline $\begin{array}{l}\text { Pinkston \& Carroll (1996) } \\
\quad \text { England }\end{array}$ & 3.49 & 3.15 & 2.29 & 0.98 \\
$\quad$ France & 3.60 & 3.04 & 2.35 & 0.98 \\
$\quad$ Germany & 2.86 & 3.21 & 2.46 & 1.42 \\
$\quad$ Japan & 3.34 & 2.76 & 2.42 & 1.41 \\
$\quad$ Sweden & 3.27 & 3.30 & 2.43 & 1.00 \\
$\quad$ Switzerland & 3.11 & 3.04 & 2.70 & 1.10 \\
$\quad$ United States & 3.31 & 2.96 & 2.48 & 1.19 \\
$\quad$ Overall average & 3.28 & 3.07 & 2.45 & 1.15 \\
\hline Edmondson \& Carroll (1999) & & & & \\
United States & 3.16 & 2.12 & 2.19 & 2.04 \\
Overall average of previous studies & 3.29 & 2.90 & 2.39 & 1.27 \\
Results of this research & 5.61 & 5.43 & 5.05 & 4.72 \\
\hline
\end{tabular}

Note. Own elaboration with previous studies information.

To continue contributing to the state of the art on the topic of CSR in Mexico and give continuity to the present investigation, some ideas are proposed next to be considered in further studies: (1) because the results seek to represent the perspective of businessmen in the service sector, it would be interesting to know the perspective of other economic sectors (e.g., commerce and industry), as well as to confirm the same order of relative importance given to the CSR dimensions; (2) other variables such as age, gender, educational level and even the socioeconomic level, could be considered as mediating variables between CSR and the financial performance of the companies (e.g., Surroca, Tribó, \& Waddock, 2010; Wang \& Bansal, 2012); and (3) the results of each of the social responsibilities between different interest groups (e.g., businessmen and consumers) could be compared, providing with this a greater understanding of the differences and similarities that exist among diverse perspectives.

It is necessary to point out that the results cannot be generalized for the whole Mexican context, this because the data only correspond to a city in the North of Mexico; to seek greater generalization, it is recommended to expand the sample size including data from other territories and sectors of the country. It would also be interesting to carry out another study to obtain a longitudinal view of the CSR orientation within the Mexican context over time.

\section{Conclusion}

The findings of the study contribute with empirical evidence on the orientation of CSR in Mexico, and suggest that the perspective of businessmen in this investigation and previous research in other countries is homogeneous in the values attributed to the social responsibilities without distinction between developing and developed countries, being the economic dimension the more important to the business sector. This topic is expected to continue to be investigated in Mexico and other countries of Latin America, the region with less information published on CSR at international level (Egri \& Ralston, 2008; Haslam, 2007).

\section{References}

Abraira, V. (2001). El índice kappa. SEMERGEN-Medicina de Familia, 27(5), 247-249. http://dx.doi.org/10.1016/S1138-3593(01)73955-X

Aupperle, K. E., Carroll, A. B., \& Hatfield, J. D. (1985). An Empirical Examination of the Relationship between Corporate Social Responsibility and Profitability. The Academy of Management Journal, 28(2), 446-463. Retrieved from http://www.jstor.org/stable/256210 
Brown, N., \& Deegan, C. (1998). The public disclosure of environmental performance information- a dual test of media agenda setting theory and legitimacy theory. Accounting and Business Research, 29(1), 21-41. http://dx.doi.org/10.1080/00014788.1998.9729564

Buysse, K., \& Verbeke, A. (2003). Proactive environmental strategies: a stakeholder management perspective. Strategic Management Journal, 24(5), 453-470. http://dx.doi.org/10.1002/smj.299

Carroll, A. B. (1979). A Three-Dimensional Conceptual Model of Corporate Performance. The Academy of Management Review, 4(4), 497-505. http://dx.doi.org/10.2307/257850

Carroll, A. B. (1991). The pyramid of corporate social responsibility: Toward the moral management of $\begin{array}{llll}\text { organizational stakeholders. } & \text { Business } & \text { Horizons, } & 34(4),\end{array}$ http://dx.doi.org/10.1016/0007-6813(91)90005-g

Carroll, A. B. (1999). Corporate Social Responsibility: Evolution of a Definitional Construct. Business \& Society, 38(3), 268-295. http://dx.doi.org/10.1177/000765039903800303

Carroll, A. B. (2008). A History of Corporate Social Responsibility: Concepts and Practices. In A. Crane, D. Matten, A. McWilliams, J. Moon, \& D. Siegel (Eds.), The Oxford Handbook of Corporate Social Responsibility (pp. 19-46). Oxford, NY: Oxford University Press Inc. http://dx.doi.org/10.1093/oxfordhb/9780199211593.003.0002

Cea, M. de los Á. (2002). Análisis multivariable: teoría y práctica en la investigación social. Madrid, España: Editorial Síntesis.

Churchill, G. A. (1979). A Paradigm for Developing Better Measures of Marketing Constructs. Journal of Marketing Research, 16(1), 64-73. http://dx.doi.org/10.2307/3150876

Crane, A., \& Matten, D. (2010). Business Ethics: Managing Corporate Citizenship and Sustainability in the Age of Globalization (3rd ed.). Oxford, NY: Oxford University Press.

Dahlsrud, A. (2008). How corporate social responsibility is defined: an analysis of 37 definitions. Corporate Social Responsibility and Environmental Management, 15(1), 1-13. http://dx.doi.org/10.1002/csr.132

Edmondson, V. C., \& Carroll, A. B. (1999). Giving Back: An Examination of the Philanthropic Motivations, Orientations and Activities of Large Black-Owned Businesses. Journal of Business Ethics, 19(2), 171-179. http://dx.doi.org/10.1023/a:1005993925597

Egri, C. P., \& Ralston, D. A. (2008). Corporate responsibility: A review of international management research from 1998 to 2007. Journal of International Management, 14(4), 319-339. http://dx.doi.org/10.1016/j.intman.2007.09.003

Escobar-Pérez, J., \& Cuervo-Martínez, A. (2008). Validez de contenido y juicio de expertos: una aproximación a su utilización. Avances en medición, 6(1), 27-36. Retrieved from http://www.humanas.unal.edu.co/psicometria/files/7113/8574/5708/Articulo3_Juicio_de_expertos_27-36.pd $\mathrm{f}$

Esrock, S. L., \& Leichty, G. B. (1998). Social responsibility and corporate web pages: Self-Presentation or $\begin{array}{llll}\text { Agenda-Setting? } & \text { Public } & \text { Relations }\end{array}$ http://dx.doi.org/10.1016/S0363-8111(99)80142-8

Freeman, B. (2006). Substance Sells: Aligning Corporate Reputation and Corporate Responsibility. Public Relations Quarterly, 51(1), 12-19.

Friedman, M. (1962). Capitalism and Freedom. Chicago, United States: University of Chicago Press.

Godfrey, P. C., Merrill, C. B., \& Hansen, J. M. (2009). The relationship between corporate social responsibility and shareholder value: an empirical test of the risk management hypothesis. Strategic Management Journal, 30(4), 425-445. http://dx.doi.org/10.1002/smj.750

Hair, J. F., Anderson, R. E., Tatham, R. L., \& Black, W. (2000). Análisis Multivariante (5th ed.). Madrid, España: Pearson Prentice Hall.

Haslam, P. A. (2007). Is Corporate Social Responsibility a Constructivist Regime? Evidence from Latin America. Global Society, 21(2), 269-296. http://dx.doi.org/10.1080/13600820701201996

Hinkle, D. E., Wiersma, W., \& Jurs, S. G. (2003). Applied Statistics for the Behavioral Sciences (5th ed.). Boston, United States: Houghton Mifflin Publisher.

Homburg, C., Kuester, S., \& Krohmer, H. (2013). Marketing Management: A Contemporary Perspective (2nd 
ed.). McGraw-Hill Higher Education. http://dx.doi.org/10.1108/03090561211189347

Lichtenstein, D. R., Drumwright, M. E., \& Braig, B. M. (2004). The Effect of Corporate Social Responsibility on Customer Donations to Corporate-Supported Nonprofits. Journal of Marketing, 68(4), 16-32. http://dx.doi.org/10.1509/jmkg.68.4.16.42726

Maignan, I. (2001). Consumers' Perceptions of Corporate Social Responsibilities: A Cross-Cultural Comparison. Journal of Business Ethics, 30(1), 57-72. http://dx.doi.org/10.1023/a:1006433928640

Maignan, I., \& Ferrell, O. C. (2000). Measuring Corporate Citizenship in Two Countries: The Case of the United States and France. Journal of Business Ethics, 23(3), 283-297. http://dx.doi.org/10.1023/a:1006262325211

Martínez, M. R., Hernández, M. J., \& Hernández, M. V. (2006). Psicometría. Madrid, España: Alianza Editorial, S. A.

McWilliams, A., Siegel, D. S., \& Wright, P. M. (2006). Corporate Social Responsibility: Strategic Implications. Journal of Management Studies, 43(1), 1-18. http://dx.doi.org/10.1111/j.1467-6486.2006.00580.x

Meyskens, M., \& Paul, K. (2010). The Evolution of Corporate Social Reporting Practices in Mexico. Journal of Business Ethics, 91(2), 211-227. http://dx.doi.org/10.1007/s10551-010-0615-x

Moura-Leite, R. C., \& Padgett, R. C. (2011). Historical background of corporate social responsibility. Social Responsibility Journal, 7(4), 528-539. http://dx.doi.org/10.1108/1747111111117511

Mukherjee, A., \& Bird, R. (2016). Analysis of mandatory CSR expenditure in India: a survey. International Journal of Corporate Governance, 7(1), 32-59. http://dx.doi.org/10.1504/ijcg.2016.077982

Nasrullah, N. M., \& Rahim, M. M. (2014). CSR in Private Enterprises in Developing Countries: Evidences from the Ready-Made Garments Industry in Bangladesh. New York, United States: Springer International Publishing. http://dx.doi.org/10.1007/978-3-319-02350-2

Painter-Morland, M., \& Vashchenko, M. (2014). Organizational CSR Portfolio: Exploration and Evaluation. Business and Professional Ethics Journal, 33(4), 351-369. http://dx.doi.org/10.5840/bpej201512319

Paul, K., Cobas, E., Ceron, R., Frithiof, M., Maass, A., Navarro, I., ... Deaton, L. Z. (2006). Corporate Social Reporting in Mexico. Journal of Corporate Citizenship, 22, 67-80. https://doi.org/10.9774/GLEAF.4700.2006.su.00009

Pett, M. A., Lackey, N. R., \& Sullivan, J. J. (2003). Making Sense of Factor Analysis: The Use of Factor Analysis for Instrument Development in Health Care Research. California, United States: SAGE Publications, Inc.

Pinkston, T. S., \& Carroll, A. B. (1996). A retrospective examination of CSR orientations: Have they changed? Journal of Business Ethics, 15(2), 199-206. http://dx.doi.org/10.1007/bf00705587

Singh, V., Rana, R. K., \& Singhal, R. (2013). Analysis of repeated measurement data in the clinical trials. Journal of Ayurveda and Integrative Medicine, 4(2), 77-81. http://dx.doi.org/10.4103/0975-9476.113872

Surroca, J., Tribó, J. A., \& Waddock, S. (2010). Corporate responsibility and financial performance: the role of intangible resources. Strategic Management Journal, 31(5), 463-490. http://dx.doi.org/10.1002/smj.820

Verbeke, A., \& Tung, V. (2013). The Future of Stakeholder Management Theory: A Temporal Perspective. Journal of Business Ethics, 112(3), 529-543. http://dx.doi.org/10.1007/s10551-012-1276-8

Wang, T., \& Bansal, P. (2012). Social responsibility in new ventures: profiting from a long-term orientation. Strategic Management Journal, 33(10), 1135-1153. http://dx.doi.org/10.1002/smj.1962

\section{Copyrights}

Copyright for this article is retained by the author(s), with first publication rights granted to the journal.

This is an open-access article distributed under the terms and conditions of the Creative Commons Attribution license (http://creativecommons.org/licenses/by/4.0/). 